\title{
Rb-Sr WHOLE-ROCK ISOTOPIC STUDY OF LATE ARCHAEAN AND EARLY PROTEROZOIC GRANITOID INTRUSIONS, KAINUU, EASTERN FINLAND
}

\author{
A.N. HALLIDAY, E.J. LUUKKONEN and D.R. BOWES
}

\begin{abstract}
HALLIDAY, A.N., LUUKKONEN, E.J. and BOWES, D.R., 1988: Rb-Sr wholerock isotopic study of late Archaean and early Proterozoic granitoid intrusions, Kainuu, Eastern Finland. Bull. Geol. Soc. Finland 60, Part 2, 107-113.
\end{abstract}

\begin{abstract}
A tonalite-granodiorite-granite suite emplaced during the late Archaean $\mathrm{D}_{3}$ deformational phase yields a six point isochron age of $2,500 \pm 270 \mathrm{Ma}$ and an initial ${ }^{87} \mathrm{Sr} /{ }^{86} \mathrm{Sr}$ of $0.7044 \pm 0.0018$. A rapakivi-type granite suite emplaced after the late Archaean episode and before the emplacement of early Proterozoic Jatulian dolerites yields a six point isochron age of 2,290 $\pm 110 \mathrm{Ma}$ and an initial ${ }^{87} \mathrm{Sr} /{ }^{86} \mathrm{Sr}$ of $0.7036 \pm 0.0085$. Both ages are c. 150-200 Ma younger than corresponding $\mathrm{U}-\mathrm{Pb}$ mineral ages for the same rock: the difference is interpreted as representing continued isotopic homogenization prior to uplift although the mechanism for such large scale, fluid phase mass transfer is not well understood.
\end{abstract}

Key words: granites, granodiorites, tonalite, rapakivi, absolute age, $\mathrm{Sr} / \mathrm{Rb}$, Precambrian, Kainuu, Finland.

A.N. Halliday: Department of Geological Sciences, University of Michigan, Ann Arbor, Mich 48109-1063, USA.

E.J. Luukkonen: Geological Survey of Finland, Box 237, SF-70101 Kuopio, Finland.

D.R. Bowes: Department of Geology, University of Glasgow, Glasgow G12 8QQ, Scotland.

\section{Introduction}

Three major suites of quartzofeldspathic plutonic masses occur in the Kainuu region of eastern Finland. The tonalites, which comprise the oldest of the suites, were emplaced before the development of the regionally expressed late Archaean $F_{2}$ folds and were generally co-eval with the formation of the regionally extensive c. 2.85 $\mathrm{Ga}$ old tonalitic gneisses. They and the younger tonalite-granodiorite-granite and rapakivi-type granite suites are cross-cut by the early Proterozoic (c. 2.2-2.1 Ga) Jatulian dolerites (Fig. 1; cf. Sakko 1971; Pekkarinen 1976; Hyppönen
1983; Luukkonen 1985; Luukkonen and Lukkarinen 1986, p. 10). The integration of the times of successive emplacement of these suites of pre$\mathrm{F}_{2}$ tonalite, tonalite-granodiorite-granite and rapakivi-type granite into the structural and metamorphic history of the rocks of the region (Luukkonen 1985, 1988a, 1988b) means that they are of considerable value in elucidating the late Archaean - early Proterozoic evolution of this part of the Baltic Shield. As a contribution to this $\mathrm{Rb}$-Sr isotopic studies were carried out on the three suites. While the very low $\mathrm{Rb} / \mathrm{Sr}$ ratios $(0.04-0.12)$ in the pre- $F_{2}$ tonalite suite did not permit determination of meaningful geochrono- 
logical information, whole-rock isochron ages and initial ${ }^{87} \mathrm{Sr} /{ }^{86} \mathrm{Sr}$ for the other two laterformed suites were determined and are presented here. These provide information for comparison with $\mathrm{U}-\mathrm{Pb}$ zircon ages of the two suites (cf. Luukkonen 1988b).

\section{Geological setting and petrography}

\section{Tonalite-granodiorite-granite (sample 1)}

Analysed representatives of this suite came from $20-30 \mathrm{~km} \mathrm{~W}$ of the Kuhmo greenstone belt (Fig. 1). Other larger massifs occur $10 \mathrm{~km}$ further W (Konivaara granite-granodiorite) and even larger masses in the Ilomantsi-Lieksa area 150-250 km to the SSE (Hyppönen 1983; Luukkonen and Lukkarinen 1986, fig. 7). Cross-cutting relations with late Archaean $\mathrm{F}_{2}$ folds are shown. Many of the masses occur as elongate bodies in large $\mathrm{F}_{3}$ antiforms and show some weak $\mathrm{S}_{3}$ foliation. These features and local modification of the common porphyritic/porphyroblastic texture to prophyroclastic texture by $\mathrm{D}_{4}$ structures means that their emplacement took place in the latter part of the late Archaean $\mathrm{D}_{3}$ deformational phase (cf. Luukkonen 1985, table 1; 1988a, table 1).

Plagioclase (albite-oligoclase), quartz, \pm potassium feldspar and biotite, with a grain size of $1-2 \mathrm{~mm}$, are present in varying proportions as major constituents in light grey-coloured rocks. Allanite, zircon, sphene, magnetite and apatite occur as accessory minerals and epidote and chlorite in small proportions as secondary products. Demonstration of distinctive fields of both mineralogical and chemical composition for a suite (Fig. 2) that can be shown consistently to be of late $\mathrm{D}_{3}$ emplacement was used as a basis for collecting samples for isotopic study from various (and widely spaced) masses to obtain as wide a spread as possible of $\mathrm{Rb} / \mathrm{Sr}$, rather than from one mass with the resultant much lower spread.

\section{Rapakivi-type granite (sample 2)}

There are three main intrusive masses of rapakivi-type granite $\mathrm{E}$ of the Kuhmo greenstone belt, the largest (c. $7 \times 9 \mathrm{~km}$ ) being the Tulilammet granite. Smaller stocks, apophyses and dykes also occur (Fig. 1). Cross-cutting relations with the late Archaean $D_{1}-D_{6}$ structures (as described by Luukkonen 1985) are shown, as is a finer grained marginal facies and a foliation generally parallel to the margins that was developed during emplacement and crystallization. The only structures seen to cross-cut these granite masses are the NW-NNW-trending early Proterozoic shear zones that exerted a major structural control on the emplacement of the c. 2.2-2.1 Ga Jatulian dolerite dykes.

The plutonic rocks are typically leucocratic and pinkish with phenocrysts of feldspar and, in places, of quartz. The feldspar phenocrysts vary in size but rarely exceed $5 \mathrm{~cm}$ in length. Their shapes vary from tabular to ovoid, the latter predominating in the central parts of the masses. Some of the phenocrysts have cores of microcline microperthite surrounded by albite or oligoclase. The groundmass consists mainly of potassium feldspar, quartz, oligoclase and biotite with a grain size of 3-5 mm. Accessory fluorite is conspicuous and allanite, zircon, sphene, magnetite and apatite are also present. Secondary chlorite developed from biotite is seen in places. Apophyses consist of buff to pink granite porphyry with distinctive phenocrysts of round to bipyramidal clear and commonly bluish-coloured quartz (up to $3 \mathrm{~mm}$ ), potassium feldspar phenocrysts (of maximum microcline composition, up to $10 \mathrm{~mm}$ in size, spherulitic in places and making up $1-30$ $\%$ of the rock) and some oligoclase phenocrysts (up to $2 \mathrm{~mm}$ ). The groundmass consists of quartz, plagioclase, sericite, biotite, opaque ore minerals and fluorite together with some secondary carbonate and epidote.

This rock suite has distinctive geochemical characters (Fig. 2) with $\mathrm{SiO}_{2}$ in the range 72$78 \%$, high $\mathrm{K}_{2} \mathrm{O} / \mathrm{Na}_{2} \mathrm{O}(0.6-1.7)$ and $\mathrm{Rb} / \mathrm{Sr}$ 


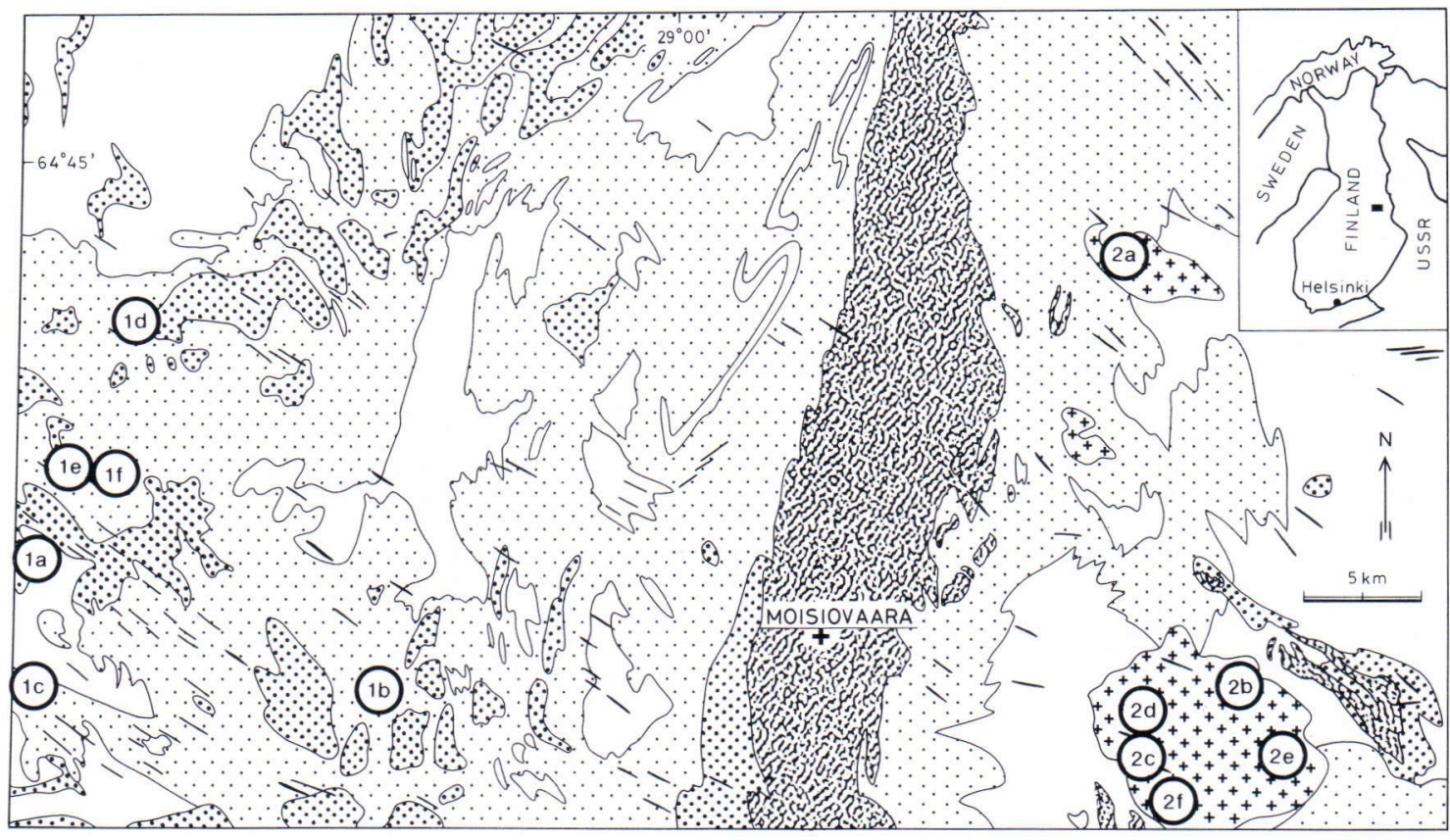

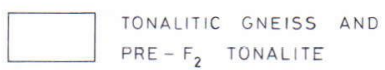

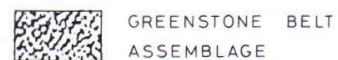

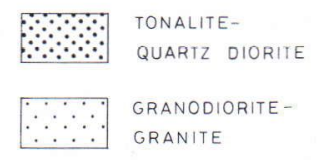

(1)-(1)

= SAMPLE, LOCALITY



(2a) - 2f

Fig. 1. Outline geological map showing the distribution of granitoid intrusions and dated samples, Kainuu region, eastern Finland; based on Luukkonen $(1986,1987)$.
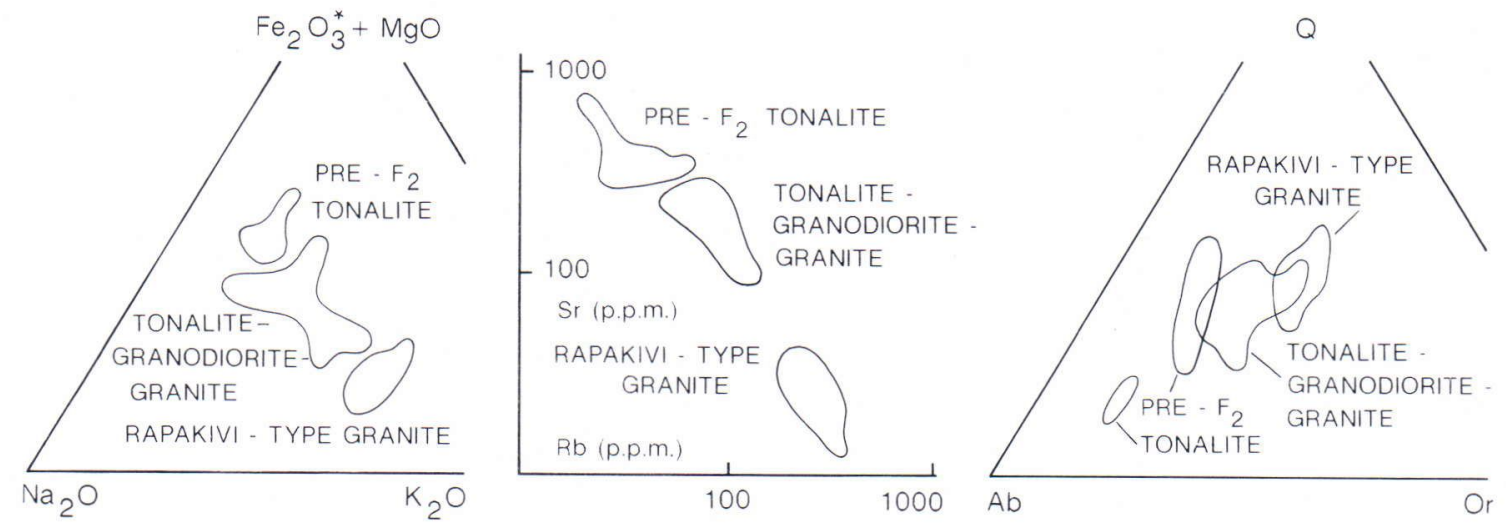

Fig. 2. Geochemical and mineralogical characters of granitoid intrusions. 
from $<1$ to nearly 40 . Normative Q-Ab-Or indicate minimum melt compositions.

\section{Analytical results and interpretation}

$\mathrm{Rb}-\mathrm{Sr}$ isotopic analysis of six whole-rock samples from each suite (located on Fig. 1) are given in Table 1 and plotted on isochron diagrams (Fig. 3). For the tonalite-granodiorite-granite suite (sample 1) the points fall on an isochron that defines an apparent age of 2,500 $\pm 270 \mathrm{Ma}$ and gives an initial ${ }^{87} \mathrm{Sr} /{ }^{86} \mathrm{Sr}$ of $0.7044 \pm 0.0018$. For the rapakivi-type granite suite (sample 2) the points fall on an isochron that defines an age of $2,290 \pm 110 \mathrm{Ma}$ and gives an initial ${ }^{87} \mathrm{Sr} /{ }^{86} \mathrm{Sr}$ of $0.7036 \pm 0.0085$.

In each case the existence of an igneous texture and a mineral assemblage that shows no evidence for metamorphic or hydrothermal activity, together with the concordant nature of the points on the isochron, would suggest that the age represents the time of crystallization. However in the case of sample $1, \mathrm{U}-\mathrm{Pb}$ isotopic study of zircon separated from specimens of the same rock suite yielded an upper intercept age of 2697 $\pm 10 \mathrm{Ma}$ (Luukkonen 1988b). In addition an aplogranite whose emplacement was controlled by late Archaean $\mathrm{D}_{4}$ structures in the nearby Lylyvaara area has yielded an upper intercept U$\mathrm{Pb}$ zircon age of 2,657 $\pm 32 \mathrm{Ma}$ (Luukkonen 1985). These U-Pb ages are 150-200 Ma older than the corresponding $\mathrm{Rb}-\mathrm{Sr}$ isochron age. Likewise an upper intercept $\mathrm{U}-\mathrm{Pb}$ zircon age of 2,435 $\pm 12 \mathrm{Ma}$ for a granite porphyry dyke which is an apophysis of the Tulilammet granite (Luukkonen 1988a) is also c. 150 Ma older than the corresponding $\mathrm{Rb}-\mathrm{Sr}$ age for the granite suite. These data suggest that in each case there was a considerable period after igneous crystallization during which there was exchange of strontium throughout the system. This is endorsed by the extreme scatter of the data.

\section{Discussion}

Other studies in both the greenstone belts and gneisses of eastern Finland have also recorded different ages for corresponding assemblages using different isotopic systems. Based on $\mathrm{Pb}-\mathrm{Pb}$ and Rb-Sr systematics Vidal et al. (1980, p. 2033)

Table 1. Rb-Sr data for granitoid intrusions.

\begin{tabular}{|c|c|c|c|c|c|}
\hline Sample & $\begin{array}{c}\mathrm{Rb} \\
\mathrm{p} \cdot \mathrm{p} \cdot \mathrm{m} .\end{array}$ & $\begin{array}{c}\mathrm{Sr} \\
\text { p.p.m. }\end{array}$ & $\begin{array}{c}\mathrm{Rb} / \mathrm{Sr} \\
\text { (wt.) }\end{array}$ & $\begin{array}{l}{ }^{87} \mathrm{Rb} /{ }^{86} \mathrm{Sr} \\
\text { (atomic) }\end{array}$ & $\begin{array}{l}{ }^{87} \mathrm{Sr} /{ }^{86} \mathrm{Sr} \\
\text { (atomic) }\end{array}$ \\
\hline \multicolumn{6}{|c|}{ Tonalite - granodiorite - granite (sample 1) } \\
\hline la tonalite & 37.41 & 554.3 & 0.06751 & 0.1954 & $0.71129 \pm 5$ \\
\hline lb tonalite & 70.06 & 389.2 & 0.1800 & 0.5219 & $0.72567 \pm 4$ \\
\hline 1c granodiorite & 91.19 & 362.1 & 0.2518 & 0.7301 & $0.72801 \pm 3$ \\
\hline 1d granite & 91.17 & 244.2 & 0.3733 & 1.084 & $0.74274 \pm 3$ \\
\hline 1e granite & 142.2 & 260.4 & 0.4769 & 1.386 & $0.75452 \pm 4$ \\
\hline If granite & 129.8 & 140.6 & 0.9232 & 2.695 & $0.79984 \pm 4$ \\
\hline \multicolumn{6}{|c|}{ Rapakivi type granite (sample 2) } \\
\hline $2 \mathrm{a}$ & 201.7 & 253.7 & 0.7950 & 2.317 & $0.78243 \pm 7$ \\
\hline $2 b$ & 255.5 & 117.5 & 2.175 & 6.419 & $0.89978 \pm 7$ \\
\hline $2 \mathrm{c}$ & 316.4 & 49.36 & 6.410 & 19.70 & $1.34125 \pm 6$ \\
\hline $2 \mathrm{~d}$ & 403.3 & 26.88 & 15.00 & 50.83 & $2.4560 \pm 20$ \\
\hline $2 \mathrm{e}$ & 445.1 & 23.80 & 18.70 & 65.63 & $2.8821 \pm 4$ \\
\hline $2 \mathrm{f}$ & 502.4 & 11.69 & 42.97 & 210.1 & $7.7627 \pm 13$ \\
\hline
\end{tabular}

Crushed samples weighed 4-6 kg; details of analytical procedures, are given in Halliday et al. $(1984) ; \lambda^{87} \mathrm{Rb}=1.42 \times$ $10^{-11} \mathrm{yr}^{-1}$; regression followed the methods of York (1969); analyses were carried out at the Isotope Geology Unit, Scottish Universities Research and Reactor Centre, East Kilbride, Glasgow G75 OQU. 

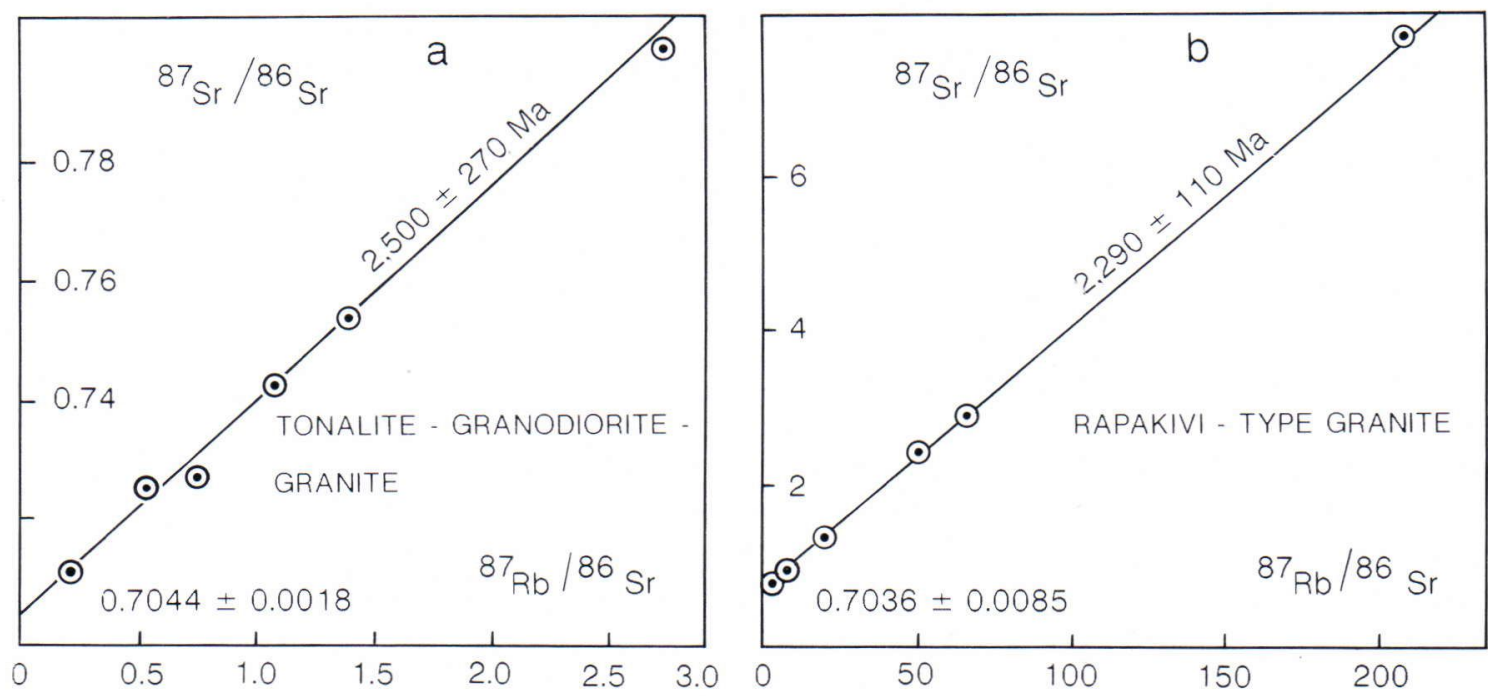

Fig. 3. Rb-Sr isochron plots for granitoid intrusions; data have been repressed according to the method of York (1969); uncertainties are $+2 \delta$ and are »scatter errors».

gave an age of $2.65 \mathrm{Ga}$ for the Suomussalmi greenstone belt ( $\mathrm{N}$ of the Kuhmo greenstone belt shown in Figure 1), and Martin et al. (1983, p. 81) used this age as representative of that of the greenstone belts of the region generally. In contrast, Hyppönen (1983) recorded a $2739 \pm 7 \mathrm{Ma}$ $\mathrm{U}-\mathrm{Pb}$ mineral age for a quartz diorite that cuts the Kuhmo greenstone belt. In the case of the gneisses, Martin et al. (1983, pp. 84, 87) recorded an $\mathrm{Rb}-\mathrm{Sr}$ whole-rock isochron of $2.62 \pm 0.7$ Ma for »the second generation of grey gneisses (Naavala type)», rocks that on the basis of regional mapping can be classed as being typical of the Archaean $\mathrm{D}_{3}$ granitoid suite for which $\mathrm{U}$ $\mathrm{Pb}$ mineral ages are c. 2,730-2,690 Ma (Luukkonen 1988a, 1988b). In both these instances the c. $2.65 \mathrm{Ma}$ (i.e. younger) ages generally correspond to $\mathrm{U}-\mathrm{Pb}$ mineral ages for quartzofeldspathic dyke emplaced during, or after, major crustal uplift (Luukkonen 1985, table 1). Accordingly they may record this geological event and indicate that there was continued isotopic homogenization of some systems prior to uplift. The U-Pb mineral isotopic data seems effectively to rule out greenstone belt and gneiss forma- tion at this time as proposed by both Vidal et al. (1980) and Martin et al. (1983).

The general correspondence of the c. 2,500 and 2,300 Ma Rb-Sr whole-rock ages of the plutonic masses recorded in this present study with the beginnings of deposition of the early Proterozoic Sariola Group and Jatuli Group, respectively (Luukkonen and Luukkarinen 1986, pp. 19, 22), together with these assemblages beginning with polymictic conglomerate and pebbly quartzite, respectively, suggest rapid crustal uplift at both times as an explanation for the cessation of isotopic exchange.

A corresponding explanation seems unlikely for the $2.50 \pm 10 \mathrm{Ga} \mathrm{Rb-Sr}$ whole-rock isochron age reported by Martin and Querré (1984, p. 294) for the Luoma acid volcanic assemblage of the Suomussalmi greenstone belt. There seems little possibility that a rock older than c. $2720 \mathrm{Ma}$ (the $\mathrm{U}-\mathrm{Pb}$ mineral age of an Archaean $\mathrm{D}_{3}$ quartz diorite that cuts this unit - - see Annual Report of the Geological Survey of Finland for 1981 (1982)) would have been subject to continued strontium exchange throughout the system after the major crustal uplift c. $2.65 \mathrm{Ma}$ ago. Wheth- 
er the explanation of the c. 200 Ma difference between the two ages is related to sampling cannot be assessed from the data presented. However the work of Martin and Querré (1984) was not carried out in conjunction with regional mapping as was both the work related to the new $\mathrm{Rb}-\mathrm{Sr}$ data presented here for the tonalite-granodiorite-granite and rapakivi granite suites and the $\mathrm{U}-\mathrm{Pb}$ mineral data to which reference is made (Hyppönen, 1983; Luukkonen 1986, 1988b). It is comparison of these data, and the associated evidence from stratigraphical and sedimentological studies, that point to continued isotopic homogenization prior to rapid uplift being a possible explanation for differences in reported ages, even though the mechanism for such large scale, fluid phase mass transfer is not well understood.

Consideration of initial ${ }^{87} \mathrm{Sr} /{ }^{86} \mathrm{Sr}$ of the tonalite-granodiorite-granite suite indicates that its source material cannot have had a long crustal history, i.e. there is no evidence for middle or early Archaean crust at depth during the late Archaean episode. Consideration of the initial ${ }^{87} \mathrm{Sr} /{ }^{86} \mathrm{Sr}$ of the suite of rapakivi-type granites,

\section{References}

Alapieti, T., 1982. The Koillismaa layered igneous complex Finland - - its structure, mineralogy and geochemistry, with emphasis on the distribution of chromium. Geol. Surv. Finland, Bull., 319, 116 p.

Halliday, A.N.; Fallick, A.E.; Hutchinson, J. \& Hildreth, $W ., 1984$. A Nd, Sr and $\mathrm{O}$ isotopic investigation into the causes of chemical and isotopic zonation in the Bishop Tuff, California. Earth Planet. Sci. Lett. 68, 379-391.

Hyppönen, V., 1983. Kallioperäkarttojen selitykset, 4411 Ontojoki, 4412 Hiisijärvi ja 4413 Kuhmo. English summary: Pre-Quaternary rocks of the Ontojoki, Hiisijärvi and Kuhmo map sheet areas. Geological map of Finland 1 : 100 000. Espoo: Geological Survey of Finland.

Kouvo, O., 1977. The use of mafic pegmatoids in geochronology. Abstracts of International Meeting for Geochronology, Cosmochronology and Isotope Geology, Paris.

Kratz, K.O. et al., 1976. Age limits of the Jatulian Complex of Karelia (in Russian). Doklady USSR Academy of Science, Geological Section 231, 1191-1194. with its high $\mathrm{Rb}$ content, is consistent with crystallization from a mantle-derived magma or melting of crust that had been derived from the mantle a short time earlier. The $2,435 \pm 12 \mathrm{Ma}$ U$\mathrm{Pb}$ zircon age for a rock from this suite almost corresponds, within errors, with the $2,455 \pm 5$ Ma age for quartz porphyries in Soviet Karelia (U-Pb zircon; Kratz et al. 1976) and it does correspond with the $2,436 \pm 5 \mathrm{Ma}$ age for large basic-ultrabasic layered intrusions in Koillismaa (UPb zircon; Kouvo 1977; Alapieti 1982) whose emplacement is indicative of a phase of continental rifting associated with the break-up of the late Archaean craton (Park et al. 1984, p. 363, fig. 2). Such a tectonic environment is consistent with the association of rapakivi -type granites with anorogenic conditions.

Acknowledgements. Thanks are expressed to the University of Glasgow for field grants and to J. Hutchison and F. MacLaren for technical assistance. The Isotope Geology Unit at the Scottish Universities Research and Reactor Centre is supported by the Natural Environment Research Council and the universities in Scotland.

Luukkonen, E.J., 1985. Structural and U-Pb isotopic study of late Archaean migmatitic gneisses of the Presvecokarelides, Lylyvaara, eastern Finland. R. Soc. Edinburgh Earth Sci., Trans., 76, 401-410.

-, 1986. Pre-Quaternary rocks, Sheet 4421 Moisiovaara. Geological Map of Finland 1: 100000.

-, 1987. Pre-Quaternary rocks, Sheet $4423+4441$ AlaVuokki. Geological Map of Finland 1: 100000.

-, 1988a. The structure and stratigraphy of the northern part of the late Archaean Kuhmo greenstone belt, eastern Finland. In Marttila, E. (ed.) Archaean Geology of the Fennoscandian Shield, 71-96. Geol. Surv. Finland, Spec: Paper 4.

—, 1988b. Kallioperäkarttojen selitykset, 4421 Moisiovaara ja 4423-4441 Ala-Vuokki. English summary: PreQuaternary rocks of the Moisiovaara and Ala-Vuokki map sheet areas. Geological map of Finland 1 : 100000. Espoo, Geological Survey of Finland.

—, \& Lukkarinen, H., 1986. Explanation to the stratigraphic map of Middle Finland. Geol. Surv. Finland, Rept Invest. 74,47 p. 
Martin, H.; Chauvel, C.; Jahn, B-M. \& Vidal, P., 1983. Rb-Sr and $\mathrm{Sm}-\mathrm{Nd}$ ages and isotopic geochemistry of Archaean granodioritic gneisses from eastern Finland. Precambrian Res. 20, 79-91.

—, \& Querré, G., 1984. A 2.5 G.a. reworked sialic crust: $\mathrm{Rb}-\mathrm{Sr}$ ages and isotopic geochemistry of late Archaean volcanic and plutonic rocks from E. Finland. Contrib. Mineral. Petrol. 85, 292-299.

Park, A.F.; Bowes, D.R.; Halden, N.M. \& Koistinen, T.J., 1985. Tectonic evolution at an early Proterozoic continental margin: the Svecokarelides of eastern Finland. J. Geodynamics $1,359-386$.

Pekkarinen, L.J., 1976. The Karelian formations and their depositional basement in the Kiihtelysvaara-Värtsilä area, East Finland. Geol. Surv. Finland, Bull., 301, 141 p.

Sakko, M., 1971. Varhais-Karjalaisten metadiabaasien radiometrisiä zirkoni-ikiä. Summary: Radiometric zircon ages of the Early-Karelian metadiabases. Geologi 23, 117-118. Vidal, P.; Blais, S.; Jahn, B-M.; Capdevila, R. \& Tilton, G.R., 1980. U-Pb and Rb-Sr systematics of the Suomussalmi Archaean greenstone belt (eastern Finland). Geochim. Cosmochim. Acta 44, 2033-2044.

York, D., 1969. Least squares fitting of a straight line with correlated errors. Earth Planet Sci Lett. 5, 320-4.

Received July 4, 1988

Revised and accepted November 28, 1988 